\title{
SOME NOTES ON OTTOMAN TAX FARMING IN HUNGARY
}

\author{
PÁL FODOR ${ }^{*}$ \\ (Budapest)
}

\begin{abstract}
On the basis of an "inventory of tax farms in the province of Buda" (defter-i fihrist-i mukataa- $i$ vilayet-i Budun), the paper describes the administration of Ottoman tax farms in Hungary in a comparative way (the reference area being the Lower Danube). Its main concern is the sixteenth-century practice but the seventeenth-century transformations are also touched upon. The widely held view that the seventeenth century saw the rapid spread of tax farming, is untenable for Hungary; in this period, the tax farms were increasingly replaced by "corporate estates" (ocaklik) not only in Hungary but in other parts of the empire as well.
\end{abstract}

Key words: Ottoman Empire, Ottoman Hungary - tax farm, finances, fiscal administration.

In 1541 the Ottomans occupied the Hungarian capital city and established the beylerbeyilik of Buda. Nevertheless, it was some time before the new province became properly organised, because in the first years it was surrounded practically by a vacuum: the province lacked districts (sancaks) that would have served as its base, while an area of no-man's-land separated the centre of the province from the nearest Ottoman strongholds, which were located to the south of the Lower Danube-Drava line. The Ottoman leadership gradually strengthened the vilayet, beginning in the south and working northwards. Their first step was to place several Rumelian sancaks, situated below the Danube and Drava rivers, under the command of the beylerbeyi of Buda. Then, after the sultan's military campaign of 1543 and the occupation of the territory by local forces, a whole series of new districts were created in southern and central Hungary. Thus, ten years after the initial military offensive, ten sancaks had already been established on Hungarian territory to the north of the Danube-Drava line. In the mid-1540s Halil Bey began a general survey of the whole area. His cadastral surveys (tahrir defterleri) allowed the treasury to replace temporary measures by a system of proper regulation concerning landownership and revenue-collection. By the second half of the 1540s, "classical" Ottoman administration had been estab-

* Pál Fodor, Institute of History of the Hungarian Academy of Sciences. H-1014 Budapest, Úri u. 53. Fax: 00-36-1-356-6373. e-mail: fod6619@ella.iif.hu 
lished in the vilayet of Buda, even if there were still a number of flaws in its operation. ${ }^{1}$

The first bodies to be established were typically those associated with the collecting of revenues, i.e. the customs houses and tax farms (the latter were closely connected to the former). All sources of disposable revenue were declared to be the property of the state, but only a part of total revenue was actually collected by the treasury. A large proportion of income was allocated as timar, ziamet and has-estates, and the holders of such estates themselves provided for the collection of their revenues. Certain village and town communities were exempt from payment of various taxes. In return, however, they were required to make contributions to the state in kind or through the provision of labour. The residents of other settlements belonging to the sultanic domains paid their taxes in the form of annual lump sums to the provincial treasury. In the sixteenth century most of the remaining amounts were collected by the fiscal administration in two ways. Direct state taxes (i.e. the ciyze and extraordinary war taxes) were gathered by tax-collectors who were temporarily employed, while the large revenues stemming from the sultanic has-estates were collected in the mukataa-system and by employing tax farmers. The great significance of this latter form is best demonstrated by some statistical data from 1578-1579: in that year the total revenue of the vilayet of Buda was 29,375,187 akçe, with the $m u$ kataa share amounting to $18,240,131$ akçe. $^{2}$

During recent decades, Ottoman tax farming has been the subject of intensive research. The results of such research have increased our understanding of the manner in which tax farming was applied in Hungary. I personally have found six works to be particularly helpful. Kate Fleet's monograph on Ottoman-Genoese economic relations puts the beginnings of tax farming in a completely new light. ${ }^{3}$ Linda $\mathrm{T}$. Darling's path-breaking and comprehensive book on the running of tax farms in the sixteenth and seventeenth centuries is indispensable for any examination of the provinces, because it provides an opportunity to compare the procedures of the imperial centre with local practice. ${ }^{4}$ Murat Çizaçka's analysis of the development of the Islamic business partnership reveals the Islamic background to Ottoman tax farming, thereby providing fundamental clues to changes occurring in Ottoman fiscal administration in the seventeenth century. ${ }^{5}$ In this respect, two pioneering works of Rhoads Murphey are also very helpful. Murphey was the first author to profoundly describe the structural transformation of Ottoman provincial finances in the seventeenth century, which was quite different from the system prevailing in earlier centuries. ${ }^{6}$ And last but not least, the late Klaus Schwarz's documentary study made it possible to es-

\footnotetext{
${ }^{1}$ Fekete (1943, pp. 3-5); Fekete (1944, p. 178); Káldy-Nagy (1968); Káldy-Nagy (1970); Káldy-Nagy (1977, pp. 19-32); Dávid (1992).

2 Ágoston $(2000$, p. 222).

${ }^{3}$ Fleet (1999, especially pp. 134-141); cf. Fleet (2001).

${ }^{4}$ Darling (1996).

${ }^{5}$ Çizakça (1996, especially pp. 140 ff).

${ }^{6}$ Murphey (1979, especially pp. $\left.261 \mathrm{ff}\right)$; Murphey (1987).
} 
tablish in detail the system of making payment to garrison soldiers from tax farm revenues and the operation of the latter at the end of the sixteenth century. ${ }^{7}$

Two major studies have so far been published on Ottoman tax farming in Hungary. The first and more important was written by Gyula Káldy-Nagy. It presents in detail the main characteristics of the system as it was applied in the sixteenth century. ${ }^{8}$ The second study, written by Elöd Vass, gives an account of the development of the Vác mukataa during the sixteenth century. ${ }^{9}$ In what follows, I wish to present several of my observations, expanding upon the conclusions of these two authors. The facts mentioned below apply (for the most part) to the sixteenth century and to the vilayet of Buda, because our sources relate mainly to that period and to that area. Still, towards the end of my contribution, I will also touch upon changes occurring in the seventeenth century. This paper was based mainly on an "inventory of tax farms in the province of Buda" (defter- $i$ fihrist-i mukataa-i vilayet-i Budun), which was kept between 1562 and 1571. The inventory allows us to follow the story of the $m u$ kataas of the province and their contractors for a period of almost ten years. ${ }^{10}$

While Káldy-Nagy found eighteen separate sections of revenue in the annual treasury account books of the vilayet for the period $1558-1560,{ }^{11}$ in the $1562-1571$ inventory as many as forty-six mukataas are registered. Two factors may explain this increase: by the time of the inventory, the treasury had, firstly, discovered all available sources of revenue and, secondly, divided off certain revenues and made them into separate mukataas. It did just this, for instance, with unclaimed inheritances and confiscated properties (beytülmal) in a whole series of sancaks, with several groups of villages that had once belonged to the mukataa of Vác, and with the "new hases", which had been separated off for the sultanic domains. At the same time the mukataas were flexibly restructured according to the requirements of the treasury and the demand of bidders. Those that were difficult to manage were deleted (fesh), while others were merged at the request of contractors. From time to time, new mukataas and tax farms were formed out of villages that were paying fixed lump sum taxes.

The inventory consistently refers to all portions of income as emanet, even though just three of the forty-six sections were administered from beginning to end by means of trusteeship (ber vech-i emanet). The rest were normally contracted out to private tax farmers by means of undertaking (ber vech-i iltizam). As was the case in other parts of the empire, any revenue could pass from the status of iltizam to ema-

\footnotetext{
${ }^{7}$ Schwarz (1997). (1962b).

${ }^{8}$ Káldy-Nagy (1962a, pp. 752-772); Káldy-Nagy (1970, pp. 55-73). Cf. Káldy-Nagy

${ }^{9}$ Vass (1971, pp. 483-490).

${ }^{10}$ Vienna, Österreichische Nationalbibliothek [henceforth ÖN], Türk. Hss. Mxt. 609. A large part of it was published in Hungarian translation by Velics - Kammerer (1886-1890, Vol. II, pp. 277-287, 289-290, 295-296, 306-307, 312-314, 318-320, 328-346, 348-353, 364-365, 378, 391-392). The signature Mxt. 593 given by Velics - Kammerer (ibid., p. 287) for the section containing the so-called maktu villages is obviously erroneous; in fact, it was rendered from the same manuscript (Mxt. 609, fols 20b-46a). For a similar, less detailed inventory from the previous decade, see Mxt. 581, fols $18 b-24 a, 28 b-34 a, 34 b-37 a$.

${ }^{11}$ Káldy-Nagy (1962a, p. 761); Káldy-Nagy (1970, p. 64).
} 
net and back. However, the fundamental method in Hungary was iltizam, and recourse was made to emanet only in the following cases: (a) on the death of a tax farmer; (b) where a term of tenure (tahvil or müddet) expired and there was no bidder; (c) where the contractor was clearly performing badly; (d) where beytülmal revenue was being collected. The main difference between the commissioner or intendant (emin) and the tax farmer (mültezim) was not what we may often read, i.e. that the former was working for a salary and the latter for a profit. ${ }^{12}$ As temporary and assistant employees of the treasury, the emins were simply passive managers of the revenue sources; they made no offers and undertook no efforts to increase revenues. ${ }^{13}$ This is why, in the case of the emanets, the amount of the mukataa is omitted in most cases - a figure that is hardly ever missing when it comes to the iltizams. In Hungary both emins and the majority of mültezims kept their previous salaries or prebends ( $b a$ ulufe-i hod / ba timar-i hod) and seldom benefited from, or used, their tax farm's resources for this purpose.

The mukataas seem to have been an area of stiff competition in sixteenthcentury Hungary. Only a small proportion of contractors held on for the usual threeyear terms. The bid and contractor's name changed six times in six years in the $m u$ kataa of Buda and Pest, six times in five years in the mukataa of Tolna, and five times in four years in the mukataa of Vörösmart, and these are average examples. In just four of forty-six units is it possible to register a decrease in the amount offered by bidders, while a constant increase in the size of the rent may be registered in the case of at least half of all mukataas. The difference between the first and last auction price is more than $20 \%$ in the case of eleven mukataas and more than $10 \%$ in the case of nineteen mukataas. In two cases the increase was as much as $46 \%$, and in one case it was as high as $175 \%$. In contrast to the data presented by L. T. Darling, the figures for Hungary show that the increase in the iltizams substantially exceeded the rate of inflation. ${ }^{14}$ At this point, it should be mentioned that the initial price of the mukataas was, in principle, determined by the amounts found in the survey registers (tahrir defterleri). The figures of the survey register of 1562 were written in above most of the mukataas in the inventory. Nevertheless these sums were usually ignored even at the first auction. If we compare the auction prices in the mukataa inventory with the projected revenues in the survey registers, we come to the unfortunate conclusion that the latter are of limited value when it comes to measuring volumes of agricultural production, or the capacity of the tax-paying population. The information provided in them simply does not reflect the real state of affairs, despite the fact that during this period the tahrirs were drawn up with much greater care and attention than fifteen or twenty years later.

It would seem that the organisation of a mukataa in Hungary involved fewer people than in the Balkans. The man in charge was the tax farmer, who was called almost without exception - emin-i mültezim which should be understood as emin ve mültezim that is commissioner and entrepreneur simultaneously. The overwhelming

\footnotetext{
${ }^{12}$ See, for instance, Gerber (1986, p. 148, note 39).

${ }^{13}$ Cf. Sahillioğlu (1962-1963, p. 147).

${ }^{14}$ Darling (1996, pp. 142-145, 178).
} 
majority of contractors in Hungary were timar-holders or garrison soldiers (officers and sometimes even ordinary troops) stationed in the country, but in rare cases local (Hungarian, Serb, and Jewish) inhabitants also crop up among them. A small nucleus is discernible which was present throughout the studied period, trying to seize the major mukataas alternately or joining forces. Business partnership in the operation of Hungarian tax farms is conspicuous, anyway. These "capitalists" of Ottoman Hungary sometimes jointly hired large mukataas simultaneously and had to rely to a large extent on their agents (amils) who were in all probability in charge of various income sources within the mukataas. ${ }^{15}$ The third constant actor in the partnerships was the scribe or record-keeper (katib) who was usually appointed upon the emin's request under the terms he set ( $b a$ şart-i...). The scribes often performed their duty by way of undertaking (ber vech-i iltizam) (sometimes in more than one mukataas), which appears to me a Hungarian specificity.

The supervision of the businessmen was seemingly the duty of the inspector called müfettiş. This function was usually performed by the kad $\imath$ s of Pest, Buda and some major centres (Szeged, Székesfehérvár, Tolna, Kalocsa, etc.). As far as it can be judged, the scope of authority of müfettişes in Hungary was radically different from that of the inspectors of Balkan mukataas (e.g. those belonging to the mukataa-i evvel bureau). ${ }^{16}$ The müfettiş of the Lower Danube mukataa district (Tuna aklamı), for example, was the chief contractor with a huge turnover of money at the head of an extensive hierarchy: subordinated to him were the chief inspector (nazıru'n-nuzzar), the inspectors (nazır) and the tax farmers (mültezim) who all had their offices by tax farm. In addition, the chief and the ordinary inspectors (nazır) often were the guarantors (kefil) and receivers of funds (kablz-i mal) of mültezims. The inventory I analysed makes no mention of nazıru'n-nuzzar in Hungary at all and nazır only very rarely, but when it does, the context is perfectly identical with that in the Balkans: as was the case there, also here the nazır was the surety of the tax farmer. While the bulk of tax farmers were local inhabitants, their guarantors were recruited from a far wider area, e.g. from Istanbul and various regions of the Balkans. The havale (assignee) office, so important in central and provincial fiscal administration, ${ }^{17}$ does not feature in the inventory either, but other sources testify to its existence in Hungary as well. Some of them were in charge of delivering the due installments of various mukataas to the provincial treasury in Buda. Another group of havales received in the presence of the kadl the sums allotted from the mukataas for the pay of the troops and took the money to the castles (they were sometimes called kabiz- $i$ $\mathrm{mal}){ }^{18}$ Since the provincial treasury of Buda spent all the income locally, the working of the mukataa system of Hungary fundamentally differed from the practice of regions belonging to the central administration, say, to the mukataa-i evvel. There the

\footnotetext{
${ }^{15}$ For amils acting in such capacity elsewhere, see Istanbul, Başbakanlık Osmanlı Arşivi [henceforth BOA], A.DVN 794, p. 106.

${ }^{16}$ All relevant information was taken from a "register of noble orders issued by the bureau mukataa-i evvel"; see BOA, MAD 6910.

${ }^{17}$ Cf. İnalcık (1986, pp. 283-285); Darling (1996, pp. 157-158).

${ }^{18}$ Schwarz (1997, p. 75).
} 
revenues were divided into funds for local expenses and funds to be delivered to the centre, the latter being taken to Istanbul in successive remittances (irsaliyye) by the havales. There were two installments: that of the New Year (nevruz irsaliyyesi) and that of August (ăgustos irsaliyyesi). Since no money was taken from the vilayet of Buda to Istanbul (but vice versa, money was brought from there), the havales were reduced to the above mentioned tasks in the provincial organisation. (However, the province of Temesvár produced surplus, so there might have been havales there in the latter function.)

The mentioned 46 mukataas in the vilayet of Buda naturally widely differed as to size and significance. For the largest ones, 1 million akçe or more was paid for three years around 1568-1570. 14 units belonged to this category, of them the mukataas of Vác, of the new sultanic has-estates and of Buda and Pest being most outstanding. The former was estimated at over 5 million, the second at 3 million, the third at nearly 2 million. For lengthier periods of time in the sixteenth century, the Vác and Buda units preserved their leading positions. It is also demonstrable that $m u$ kataas which included large has towns and harbours or crossing places were valued highest. Large mukataas often comprised ten to twenty income sources, including the imperial has-estates high in the list. Therefore, the view, also maintained by L. T. Darling that the iltizam was mainly extended to the has-estates from the late sixteenth century onward is unfounded. ${ }^{19}$ In Hungary the iltizam was the par excellence method of collecting has incomes in the sixteenth century.

As mentioned above, the other way was the payment in annual lump sum (maktu or kesim), though, if we take a closer look at it, we will find it highly similar to mukataa. The studied inventory suggests that the Ottoman fiscal administration considered maktu as a special case of mukataa. One indicator is that every maktu settlement was registered with the formula mukataa-i kariye-i/varoş-i... This variant only differs from the normal iltizam in that the community itself agreed with the treasury directly, without mediators, about the sum to be paid and also saw to the regular payment itself. That the amount of taxes was fixed as a result of a direct bargain between the community and the treasury instead of the mechanical delivery of the projected incomes of the tahrir defteris is also borne out by the fact that the lump sums always differ from the sums indicated in the defters (most surprisingly, often being lower). The other indicator is that maktu villages could be subsumed under a mukataa (iltizam) any time, and vice versa: they could be converted from iltizam to maktu. Therefore, the maktu can be seen as a special tax farm where the reaya were the entrepreneur and which could be run cheaper because the costs of the private contractor could be spared. When the reaya wished to preserve their favourable status, they behaved like the mültezims: offering more than the lump sum determined so far. Such offers are exemplified at several points in the inventory.

The "classical" iltizam system implanted by the Ottomans was fundamentally shaken by the Long Turkish War (1593-1606) and was essentially disintegrated by the seventeenth-century fiscal transformation. While tens of mukataas were regis-

${ }^{19}$ Darling (1996, p. 47, p. 142).

Acta Orient. Hung. 54, 2001 
tered earlier, the seventeenth-century account books only mention 5-10 mukataas and 9 "crossings" (ubur) and customs houses (gümrük) separately from the former. ${ }^{20}$ Incomes were also radically cut back: throughout the seventeenth century the total income from the mukataas was between 5 and 6 million akçe. In fiscal administration, changes similar to the other provinces of the empire were introduced. In addition to the fiscal inspectorate of Belgrade, the inspectorate of Vác (nezaret-i Vaç) was set up, to which not only the strictly Hungarian areas but also some mukataas in the Balkans were attached. ${ }^{21}$ This was in part due to the drastic drop in Hungary's load-bearing capacity due to the wars at the end of the sixteenth century, thus the troops stationed here had to be paid from taxes transferred from the Balkan districts. Mukataas and iltizams were increasingly replaced by "corporate estates or funds" (ocaklik) and even the greater part of the sultanic domains was converted into ocakllk funds. In Klára Hegyi's calculations, by 167798 per cent of cizye, 30 per cent of mukataas and 63 per cent of the sultanic hases were utilised as ocaklik in Hungary. ${ }^{22}$ In my view, the ocaklık can be interpreted in the following way. ${ }^{23}$ Between the administrators, soldiers and various institutions on the one hand and the sources of income allocated for their upkeep on the other, direct and long-term connection was established which largely rendered the former mediating, redistributive activities of the central and provincial treasuries redundant. As the garrison troops and other officials in Hungary gained access to such ocakliks, the treasury was less and less in need of mukataas, or constantly renewed undertakings, as the corps of recipients themselves provided for the collection of income assigned to them. Consequently, the widely spread view in scholarly literature that the seventeenth century was the age of the expansion of tax farming is perfectly untenable for Hungary. ${ }^{24}$ As far as I see, it is unfounded for the whole of the empire for the ocakllk as a method of distribution and collection of revenues underwent immense development elsewhere (mainly in the frontier areas), too. ${ }^{25}$ That the Anatolian tax farm contracts dropped from 602 at the beginning of the sixteenth century to 309 in 1636 ought to have been seen as a serious warning by itself. ${ }^{26}$ True, from the mid-sixteenth century tax farming penetrated spheres where it had not been used earlier (e.g. sancakbeyilik by way of iltizam, farming out the beys' and pashas' hases to their voyvodas, etc.) but that is

${ }^{20}$ BOA, MAD 5193, p. 3; Bab-i defteri, Baş muhasebe, Budun hazinesi kalemi, 16727, p. $6 ; 16728$, p. $6 ; 16729$, pp. $4-6$.

${ }^{21}$ The first references to the two fiscal units I could uncover stem from 1591 (Belgrade) and 1611-1613 (Belgrade and Vác); see BOA, MAD 9820, p. 69 and Vienna, ÖN, Türk. Hss. Mxt 612, pp. $46-47$.

${ }_{22}^{22}$ Hegyi (manuscript). 219-232).

${ }^{23}$ Cf. Murphey (1979, pp. 187-208); Göyünç (1991, pp. 274-277); Çizakça (1993, pp.

${ }^{24}$ For a succinct summary of this traditional view, see Cvetkova (1964). The seventeenthcentury changes have generally been perceived in terms of decentralisation and decline in Ottoman state administration which have broadly been linked to the spread of tax farms; on this, see also İnalcık (1977); İnalcık (1980, pp. 327-333). Recently, the decline thesis has attracted a good deal of criticism; for a balanced overview of the question, see Kafadar (1997-1998).

${ }^{25}$ On the Eastern frontier, see Murphey (1987).

${ }^{26}$ Barkan (1953-1954, p. 297); Murphey (1987, pp. XXVI-XXVII). 
only one aspect of the changes. ${ }^{27}$ The local investigations presented above and requiring further research will hopefully contribute to a break away from the commonplaces reiterated about seventeenth-century fiscal administration, including one of the most conspicuous ones: the idea of the explosion of tax farming.

\section{References}

Ágoston, G. (2000): The Costs of the Ottoman Fortress-System in Hungary in the Sixteenth and Seventeenth Centuries. In: Dávid, G. - Fodor, P. (eds): Ottomans, Hungarians, and Habsburgs in Central Europe. The Military Confines in the Era of Ottoman Conquest. LeidenBoston-Köln, pp. 195-228. (The Ottoman Empire and its Heritage. Politics, Society and Economy. Faroqhi, S. - İnalcık, H. eds, Vol. 20).

Barkan, Ö. L. (1953-1954): H. 933-934 (M. 1527-1528) malî y1lına ait bir bütçe örneği. İstanbul Üniversitesi İktisat Fakültesi Mecmuast Vol. 15, pp. 251-329.

Çizakça, M. (1993): Tax-Farming and Financial Decentralization in the Ottoman Economy, 15201697. The Journal of European Economic History Vol. 22, No. 2, pp. 219-250.

Çizakça, M. (1996): A Comparative Evolution of Business Partnerships. The Islamic World and Europe, with Specific Reference to the Ottoman Archives. Leiden-New York-Köln. (The Ottoman Empire and its Heritage. Politics, Society and Economy. Faroqhi, S.-İnalcık, H. eds, Vol. 8.)

Cvetkova, B. (1964): Recherches sur le système d'affermage (Iltizam) dans l'Empire Ottoman au cours de $\mathrm{XVI}^{\mathrm{e}}-\mathrm{XVIII}{ }^{\mathrm{e}}$ s. par rapport aux contrées Bulgares. Rocznik Orientalistyczny Vol. 27, pp. 111-132.

Darling, L. T. (1996): Revenue-Raising and Legitimacy. Tax Collection and Finance Administration in the Ottoman Empire 1560-1660. Leiden-New York-Köln. (The Ottoman Empire and its Heritage. Politics, Society and Economy. Faroqhi, S.-İnalcık, H. eds, Vol. 6.)

Dávid, G. (1992): Incomes and Possessions of the Beglerbegis of Buda in the Sixteenth Century. In: Veinsten, G. (ed.): Soliman le Magnifique et son temps. Süleyman the Magnificent and his Time. Paris, pp. 385-398. (Reprinted in Dávid, G. [1997]: Studies in Demographic and Administrative History of Ottoman Hungary. Istanbul, pp. 103-117. [Analecta Isisiana, XXV].)

Fekete, L. (1943): Az esztergomi szandzsák 1570. évi adóösszeírása. Budapest.

Fekete, L. (1944): Budapest a törökkorban. Budapest. (Budapest története. Károly Szendy ed. III.)

Fleet, K. (1999): European and Islamic Trade in the Early Ottoman State. The Merchants of Genoa and Turkey. Cambridge. (Cambridge Studies in Islamic Civilization.)

Fleet, K. (2001): Appalto and gabella: Farmed Tax or Monopoly? In: Jeremiás, É. M. (ed.): IranoTurkic Cultural Contacts in the 11th-17th Centuries. Piliscsaba.

Gerber, H. (1986): Jewish Tax-Farmers in the Ottoman Empire in the 16th and 17th Centuries. Journal of Turkish Studies Vol. 10, pp. 143-154.

Göyünç, N. (1991): Yurtluk-ocaklık deyimleri hakkında. In: Prof. Dr. Bekir Kütükoğlu'na armağan. İstanbul, pp. 269-277.

Hegyi, K. (manuscript): Fiscal Policy in the vilayet of Buda in the Seventeenth Century.

İnalcık, H. (1977): Centralization and Decentralization in Ottoman Administration. In: Naff, Th.Owen, R. (eds): Studies in Eighteenth Century Islamic History. Carbondale-Edwardswille-London-Amsterdam, pp. 27-52, 362-369.

${ }^{27}$ On this, see Röhrborn (1973, pp. 107 ff). 
İnalcık, H. (1980): Military and Fiscal Transformation in the Ottoman Empire, 1600-1700. Archivum Ottomanicum Vol. 6, pp. 283-337.

İnalcık, H. (1986): Hawāla. In: The Encyclopaedia of Islam. New ed. Vol. III. Leiden-London, pp. $283-285$.

Kafadar, C. (1997-1998): The Question of Ottoman Decline. Harvard Middle Eastern and Islamic Review Vol. 4, Nos 1-2, pp. 30-75.

Káldy-Nagy, Gy. (1962a): Das Kassabuch. In: Fekete, L.-Káldy-Nagy, Gy. (eds): Rechnungsbücher türkischer Finanzstellen in Buda (Ofen) 1550-1580. Türkischer Text. Budapest, pp. $752-772$.

Káldy-Nagy, Gy. (1962b): The Cash Book of the Ottoman Treasury in Buda in the Years 15581560. $A O H$ 15, pp. 173-182.

Káldy-Nagy, Gy. (1968): The Administration of the sanjāq Registration in Hungary. AOH 21, pp. 181-223.

Káldy-Nagy, Gy. (1970): Magyarországi török adóösszeirások. Budapest. (Értekezések a történeti tudományok köréből. János Varga ed. Új sorozat, 52.)

Káldy-Nagy, Gy. (1977): A budai szandzsák 1559. évi összeirása. Budapest. (Pest megye múltjából, 3.)

Murphey, Rh. (1979): The Functioning of the Ottoman Army under Murad IV (1623-39/10321049): Key to the Understanding of the Relationship between Center and Periphery in Seventeenth-Century Turkey. Unpublished Ph.D. Dissertation, University of Chicago.

Murphey, Rh. (1987): Regional Structure in the Ottoman Economy. A Sultanic Memorandum of 1636 A.D. Concerning the Sources and Uses of the Tax-Farm Revenues of Anatolia and the Coastal and Northern Portions of Syria. Wiesbaden. (Near and Middle East Monographs, New Series, Vol. 1.)

Röhrborn, K1. (1973): Untersuchungen zur osmanischen Verwaltungsgeschichte. Berlin-New York. (Studien zur Sprache, Geschichte und Kultur des islamischen Orients. Beihefte zur Zeitschrift Der Islam. Spuler, B. ed. N. F. Bd. 5.)

Sahillioğlu, H. (1962-1963): Bir mültezim zimem defterine göre XV. yüzyıl sonunda Osmanlı darbhane mukataaları. İstanbul Üniversitesi İktisat Fakültesi Mecmuası Vol. 23, pp. $145-218$.

Schwarz, Kl. (1997): Osmanische Sultansurkunden. Untersuchungen zur Einstellung und Besoldung osmanischer Militärs in der Zeit Murāds III. Aus dem Nachlass herausgegeben von C. Römer. Stuttgart. (Freiburger Islamstudien. Roemer, H. R.-Ende, W. eds, Bd. XVII.)

Vass, E. (1971): Eléments pour compléter l'histoire de l'administration des finances du vilayet de Buda au XVI e siècle. In: Ligeti, L. (ed.): Studia Turcica. Budapest, pp. 483-490. (Bibliotheca Orientalis Hungarica, XVII.)

Velics, A. - Kammerer, E. (1886-1890): Magyarországi török kincstári defterek. I-II. Budapest. 